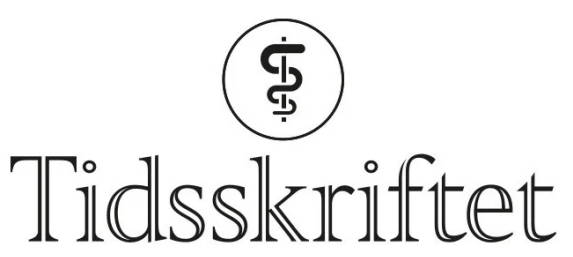

DEN NORSKE LEGEFORENING

\title{
Schistosomiasis hos norske studenter etter opphold i Afrika
}

ORIGINALARTIKKEL

\section{TRYGVE KRISTIANSEN}

trygve.kristiansen@helse-bergen.no

Nasjonal kompetansetjeneste for tropiske infeksjonssykdommer

Infeksjonsseksjonen

Medisinsk avdeling

Haukeland universitetssjukehus

og

Mikrobiologisk avdeling

Haukeland universitetssjukehus

Han har bidratt med utforming og design, datainnsamling, analyse og tolkning av data, litteratursøk, og utarbeiding og revisjon av manus.

Trygve Kristiansen er spesialist i indremedisin.

Forfatteren har fylt ut ICMJE-skjemaet og oppgir ingen interessekonflikter.

\section{FRANK OLAV PETTERSEN}

Regional kompetansetjeneste for import- og tropesykdommer Infeksjonsmedisinsk avdeling

Oslo universitetssykehus, Ullevål sykehus

Han har bidratt med ide, utforming og design, datainnsamling, analyse og tolkning av data,

litteratursøk og utarbeiding og revisjon av manus.

Frank Olav Pettersen er ph.d., spesialist i infeksjonssykdommer og medisinsk mikrobiologi, overlege og enhetsleder.

Forfatteren har fylt ut ICMJE-skjemaet og oppgir ingen interessekonflikter.

\section{TORE LIER}

Avdeling for mikrobiologi og smittevern

Universitetssykehuset Nord-Norge, Tromsø

og

Folkhälsomyndigheten, Sverige

Han har bidratt med utforming og design, analyse og tolkning av data, litteratursøk, og utarbeiding og revisjon av manus.

Tore Lier er ph.d., spesialist i medisinsk mikrobiologi og overlege. Han er leder for Nasjonal referansefunksjon for serologisk parasittdiagnostikk og medisinsk ansvarlig for parasittologi i Folkhälsomyndigheten i Sverige.

Forfatteren har fylt ut ICMJE-skjemaet og oppgir ingen interessekonflikter.

\section{SVEN GUDMUND HINDERAKER}

Senter for internasjonal helse

Universitetet i Bergen

Han har bidratt med ide, utforming og design, datainnsamling, analyse og tolkning av data, litteratursøk og utarbeiding og revisjon av manus. 
Sven Gudmund Hinderaker er dr.med. og professor.

Forfatteren har fylt ut ICMJE-skjemaet og oppgir ingen interessekonflikter.

\section{GOTTFRIED GREVE}

Klinisk institutt 2

Det medisinske fakultet

Universitetet i Bergen

og

Hjerteavdelingen

Haukeland universitetssjukehus

Han har bidratt med utforming og design, datainnsamling, analyse og tolkning av data, litteratursøk og utarbeiding og revisjon av manus.

Gottfried Greve er dr.med., professor og seksjonsoverlege.

Forfatteren har fylt ut ICMJE-skjemaet og oppgir ingen interessekonflikter.

\section{KRISTINE MØRCH}

Nasjonal kompetansetjeneste for tropiske infeksjonssykdommer

Infeksjonsseksjonen

Medisinsk avdeling

Haukeland universitetssjukehus

og

Klinisk institutt 2

Det medisinske fakultet

Universitetet i Bergen

Hun har bidratt med ide, utforming og design, datainnsamling, analyse og tolkning av data,

litteratursøk og utarbeiding og revisjon av manus.

Kristine Mørch er ph.d., spesialist i infeksjonssykdommer, overlege og førsteamanuensis. Hun er

leder for Nasjonal kompetansetjeneste for tropiske infeksjonssykdommer ved Haukeland

universitetssjukehus.

Forfatteren har fylt ut ICMJE-skjemaet og oppgir ingen interessekonflikter.

\section{BAKGRUNN}

Schistosomiasis er en tropisk infeksjonssykdom der alvorlig sykdomsforløp kan forebygges ved tidlig diagnose og behandling. Denne studien undersøkte forekomst og diagnostikk av schistosomiasis hos norske utvekslingsstudenter som hadde vært eksponert for ferskvann i Afrika.

\section{MATERIALE OG METODE}

Studenter $(n=318)$ fra Bergen og Oslo som hadde hatt utveksling til Afrika i perioden 200318, ble kontaktet og inkludert i studien hvis de hadde vært eksponert for ferskvann under oppholdet. Rutineutredning med Schistosoma-antistofftest, mikroskopi og/eller PCRundersøkelse av urin og feces, urinstiks og blodprøver til analyse av eosinofile granulocytter, kreatinin og total-IgE ble utført. Tid, sted og type eksponering og symptomer ble registrert i et spørreskjema.

\section{RESULTATER}

Av 151 studenter som ble inkludert i studien, ble Schistosoma-antistoffer påvist hos 46 (30\%). Ingen seropositive fikk påvist egg i urin eller feces, og ingen hadde eosinofili. To studenter rapporterte om svømmekløe, mens én hadde hatt symptomer forenlige med akutt schistosomiasis. Rafting var oppgitt som eneste form for ferskvannseksponering hos 22 av $40(55 \%)$ av de seropositive.

\section{FORTOLKNING}

En høy andel av studentene som hadde vært eksponert for ferskvann, fikk påvist schistosomiasis. Flertallet hadde ikke hatt noen symptomer. Rafting var hyppigste form for eksponering. Alle ble diagnostisert med serologisk analyse, mens annen rutinediagnostikk av schistosomiasis var mindre nyttig. Serologisk analyse bør være den foretrukne testformen for diagnostisering av schistosomiasis hos reisende. 
Schistosomiasis ble påvist ved serologisk analyse hos 46 av 151 (30 \%) studenter som hadde vært i kontakt med ferskvann i Afrika.

Rafting i Nilen var vanligste type ferskvannseksponering.

Rutinediagnostikk med mikroskopi og/eller PCR-undersøkelse av urin og feces ga negativt resultat hos alle de seropositive.

Schistosomiasis er en parasittær infeksjonssykdom forårsaket av blodikter i slekten Schistosoma (1). De seks viktigste artene som gir sykdom hos mennesker, er S. haematobium, S. mansoni, S. japonicum, S. intercalatum, S. guineensis og S. mekongi. Mennesker blir smittet ved kontakt med ferskvann der det finnes parasitter i et bevegelig larvestadium (cercarier) som kan penetrere hel hud. De voksne ormene som lever i venene rundt urinblære og tarm, produserer egg som enten retineres i vevet eller utskilles til omgivelsene. For $S$. haematobium og S. mansoni er mennesket hovedvert, mens infeksjoner med S. japonicum, $S$. intercalatum, S. guineensis og S. mekongi er zoonoser (르). Egg i urin og feces som når ferskvann, frigir miracidier som kan infisere noen bestemte snegler, og etter aseksuell replikasjon i sneglene frigis infeksiøse cercarier. De voksne ormene unnviker immunforsvaret og lever i gjennomsnitt 3-10 år, men opptil 4o år gamle ormer er beskrevet (므). Livssyklus for Schistosoma er illustrert i figur 1. Egg som retineres i vevet, forårsaker granulomatøs inflammasjon. Vedvarende inflammasjon kan forårsake senkomplikasjoner i form av levercirrhose, cor pulmonale og urogenital schistosomiasis. En sjelden, men fryktet komplikasjon er nevroschistosomiasis, som skyldes inflammasjon rundt ektopiske egg i sentralnervesystemet $(\underline{2}, 3)$.

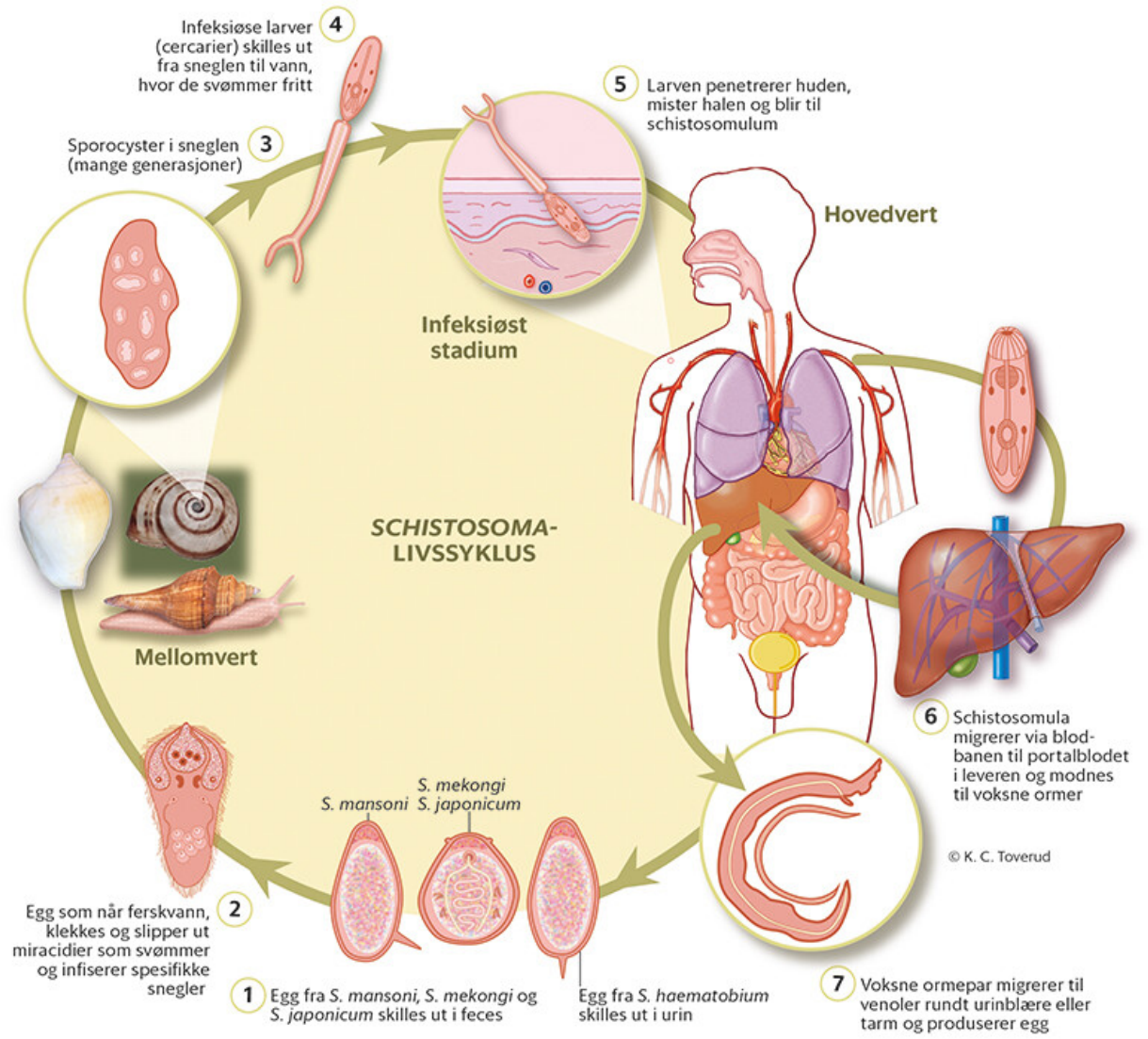

Figur 1 Schistosoma-parasittenes livssyklus.

I 2017 estimerte WHO at minst 220 millioner mennesker var infisert med Schistosoma globalt, men grunnet pågående massebehandling antar man at forekomsten nå er omtrent 140 millioner $(\mathbf{1}, 4$. .). Over $90 \%$ av de infiserte lever i Afrika, men sykdommen forekommer også i Karibia, Sør-Amerika, Midtøsten og Asia. Fra 2013 er det også rapportert om innenlandssmitte på Korsika $(\underline{2}, 5)$. Schistosomiasis regnes som en av de neglisjerte tropiske 
infeksjonssykdommene, og den forårsaker høy morbiditet og mortalitet, særlig blant fattige i endemiske områder der smittetrykket er stort. Sykdom hos reisende fra ikkeendemiske områder er velkjent, men gir mindre grad av kroniske sykdomsmanifestasjoner på grunn av mer begrenset eksponering og lavere ormebyrde $(\underline{6}, 7.7)$. Nevroschistosomiasis er imidlertid beskrevet blant reisende i flere kasuistikker ( $\underline{8-10})$. Akutt schistosomiasis, også kalt Katayama-feber og Katayama-syndrom, har vært rapportert hos 7-34\% av europeiske reisende og kan typisk gi symptomer fire til åtte uker etter eksponering i form av feber, urtikaria og allmennsymptomer $(\underline{6}, \underline{11})$.

Studenter fra Bergen og Oslo har de siste årene hatt regelmessige utvekslingsopphold i Afrika, hovedsakelig i Uganda. Ved Nasjonal kompetansetjeneste for tropiske infeksjonssykdommer ved Haukeland universitetssjukehus og Regional kompetansetjeneste for import- og tropesykdommer ved Oslo universitetssykehus registrerte vi en $\emptyset$ kende etterspørsel etter schistosomiasisdiagnostikk fra studenter. Samtidig registrerte vi at mange testet positivt etter eksponering for ferskvann. Vi startet derfor i 2017 en observasjonsstudie blant tidligere utvekslingsstudenter for å undersøke forekomsten av schistosomiasis, type eksponering, symptomer og kliniske tegn, og sammenlignet diagnostiske metoder.

\section{Materiale og metode}

Alle medisinstudenter som utvekslet til Afrika fra Universitetet i Bergen i perioden 2003-17 $(n=299)$, samt en gruppe studenter som utvekslet til Uganda fra OsloMet i Oslo i 2018 ( $n=$ 19), ble kontaktet. Hvis de selv vurderte å ha hatt ferskvannskontakt under oppholdet, ble de anbefalt å teste seg for schistosomiasis. Studenter som oppgav å ha hatt ferskvannskontakt, og som samtykket, ble inkludert i studien. Studenter som hadde mottatt adekvat behandling for schistosomiasis med prazikvantel etter eksponering, ble ekskludert.

Det ble utført rutinediagnostikk i form av blodprøve for Schistosoma-serologi, IgE, eosinofile granulocytter og kreatinin, mikroskopi og/eller PCR-undersøkelse av urin og feces, og urinstiks for hemoglobin. Avhengig av bosted ble deltakerne testet hos fastlege, på lokalsykehuset eller ved studiesentrene ved poliklinikken på Haukeland universitetssjukehus eller Oslo universitetssykehus. Serologiske analyser ble utført ved Folkhälsomyndigheten i Sverige eller ved Leiden University Medical Center i Nederland. Ved begge laboratorier utføres serologiske analyser med immunfluorescensassay (IFA) for påvisning av antistoffer mot ulike antigener hos voksne ormer, og ELISA (enzyme-linked immunosorbent assay) for påvisning av IgG mot oppløselig egg-antigen.

Deltakerne ble bedt om å fylle ut et spørreskjema som inneholdt spørsmål om eksponeringstype og -tidspunkt samt symptomer og tegn relatert til schistosomiasis.

Studien var godkjent av Regional komité for medisinsk og helsefaglig forskningsetikk (2018/175/REK nord), og alle deltakerne samtykket skriftlig til å delta i studien.

\section{Resultater}

Av 318 personer som ble kontaktet, ble 151 (47\%) inkludert i studien. Av de 194 som responderte, ble 28 ekskludert på grunn av manglende ferskvannskontakt, 14 på grunn av adekvat selvbehandling med prazikvantel og 1 fordi vi ikke mottok testresultater.

I gruppen fra Oslo fikk 12 av 18 studenter stilt diagnosen schistosomiasis av lokalt helsevesen i Uganda rundt to uker etter første mulige ferskvannseksponering. Disse fikk behandling med prazikvantel, men siden diagnostikk så kort tid etter eksponering regnes 
som usikker og behandlingen ble gitt før den kan forventes å ha effekt, ble de ikke ekskludert. Vi har ikke dokumentasjon på hva slags diagnostikk som ble utført på innsamlet materiale i Uganda (urin, feces og blod).

Alle de inkluderte studentene fikk utført serologisk test, mens noen studenter avsto fra øvrig diagnostisk testing. Schistosoma-antistoff ble påvist hos 46 av de 151 (30\%) studentene som ble inkludert i studien. Resultater fra annen rutinediagnostikk hos personene vi mottok prøvesvar fra, er vist i tabell 1.

\section{Tabell 1}

Rutinetester for schistosomiasis blant seropositive og -negative studenter $(n=151)$. Tabellen viser antall (\%) med positivt resultat av antall som fikk utført de ulike testene.

\begin{tabular}{|lcr|}
\hline Test & Seropositive $(\boldsymbol{n}=46)$ & Seronegative $(\boldsymbol{n}=105)$ \\
\hline Mikroskopi, feces & $0 / 33(0)$ & $0 / 35(0)$ \\
\hline PCR, feces & $0 / 5(0)$ & $0 / 4(0)$ \\
\hline Mikroskopi, urin & $0 / 28(0)$ & $0 / 26(0)$ \\
\hline PCR, urin & $0 / 3(0)$ & $0 / 2(0)$ \\
\hline Mikroskopisk hematuri & $4 / 23(17)$ & $2 / 26(8)$ \\
\hline Forhøyet total-IgE & $6 / 23(26)$ & $1 / 25(4)$ \\
\hline Eosinofili & $0 / 22(0)$ & $0 / 37(0)$ \\
\hline Forhøyet kreatinin & $0 / 19(0)$ & $0 / 23(0)$ \\
\hline
\end{tabular}

Gjennomsnittlig tid fra eksponering til testing hos de seropositive var 4 år (fra o til 13 år). Gjennomsnittlig tid fra eksponering til testing hos de seronegative var 3 år (fra o til 12 år).

Ingen av de seropositive fikk påvist egg ved mikroskopi av urin eller feces. Ingen hadde eosinofili eller forhøyet kreatininnivå. 17 \% hadde mikroskopisk hematuri, mens $26 \%$ hadde forhøyet IgE-nivå.

To av de seropositive studentene rapporterte om symptomer på svømmekløe i forbindelse med ferskvannskontakt, én om symptomer forenlige med akutt schistosomiasis i ukene etter eksponering, og to om makroskopisk hematuri på et senere tidspunkt. I tillegg til hematuri kan hematospermi, vaginale blødninger, dysuri, diare, blod i feces og kronisk utmattelse forekomme ved kronisk schistosomiasis. Slike symptomer og tegn kan imidlertid også ha mange andre årsaker, og ble rapportert om med tilnærmet lik hyppighet av seropositive og seronegative deltakere (tabell 2).

\section{Tabell 2}

Symptomer og tegn blant seropositive og -negative studenter eksponert for ferskvann i Afrika $(n=151)$. Tabellen viser antall (\%) som rapporterte om symptomer, av antall som besvarte de ulike spørsmålene.

\begin{tabular}{|lrr|}
\hline Symptomer og tegn & Seropositive $(\boldsymbol{n}=46)$ & \multicolumn{2}{c|}{ Seronegative $(\boldsymbol{n}=105)$} \\
\hline Svømmekløe & $2 / 42(5)$ & $0 / 77(0)$ \\
\hline Akutt schistosomiasis & $1 / 41(2)$ & $0 / 77(0)$ \\
\hline Kronisk utmattelse & $2 / 41(5)$ & $3 / 77(4)$ \\
\hline
\end{tabular}




\begin{tabular}{|lrr|}
\hline Symptomer og tegn & Seropositive $(\boldsymbol{n}=46)$ & Seronegative $(\boldsymbol{n}=105)$ \\
\hline Hematuri & $2 / 42(5)$ & $0 / 77(0)$ \\
\hline Dysuri & $1 / 42(2)$ & $3 / 76(4)$ \\
\hline Hematospermi & $1 / 16(6)$ & $1 / 19(5)$ \\
\hline Vaginale blødninger & $1 / 24(4)$ & $2 / 57(4)$ \\
\hline Diare & $4 / 42(10)$ & $9 / 76(12)$ \\
\hline Blod i feces & $2 / 42(5)$ & $5 / 77(6)$ \\
\hline
\end{tabular}

Blant de seropositive oppgav 40 ferskvannskontakt i Uganda, 2 i Tanzania, 1 i Kenya, 1 i Burkina Faso, 1 i Kamerun og 1 i Laos. Rafting i Nilen var oppgitt som eneste type eksponering for ferskvann hos $55 \%$ (22 av 40) av de seropositive studentene. Av alle som angav rafting som eneste form for ferskvannskontakt, ble Schistosoma-antistoffer påvist hos $49 \%$ (22 av 45). Ulike typer eksponering for ferskvann blant de som fikk påvist schistosomiasis, er vist i figur 2.

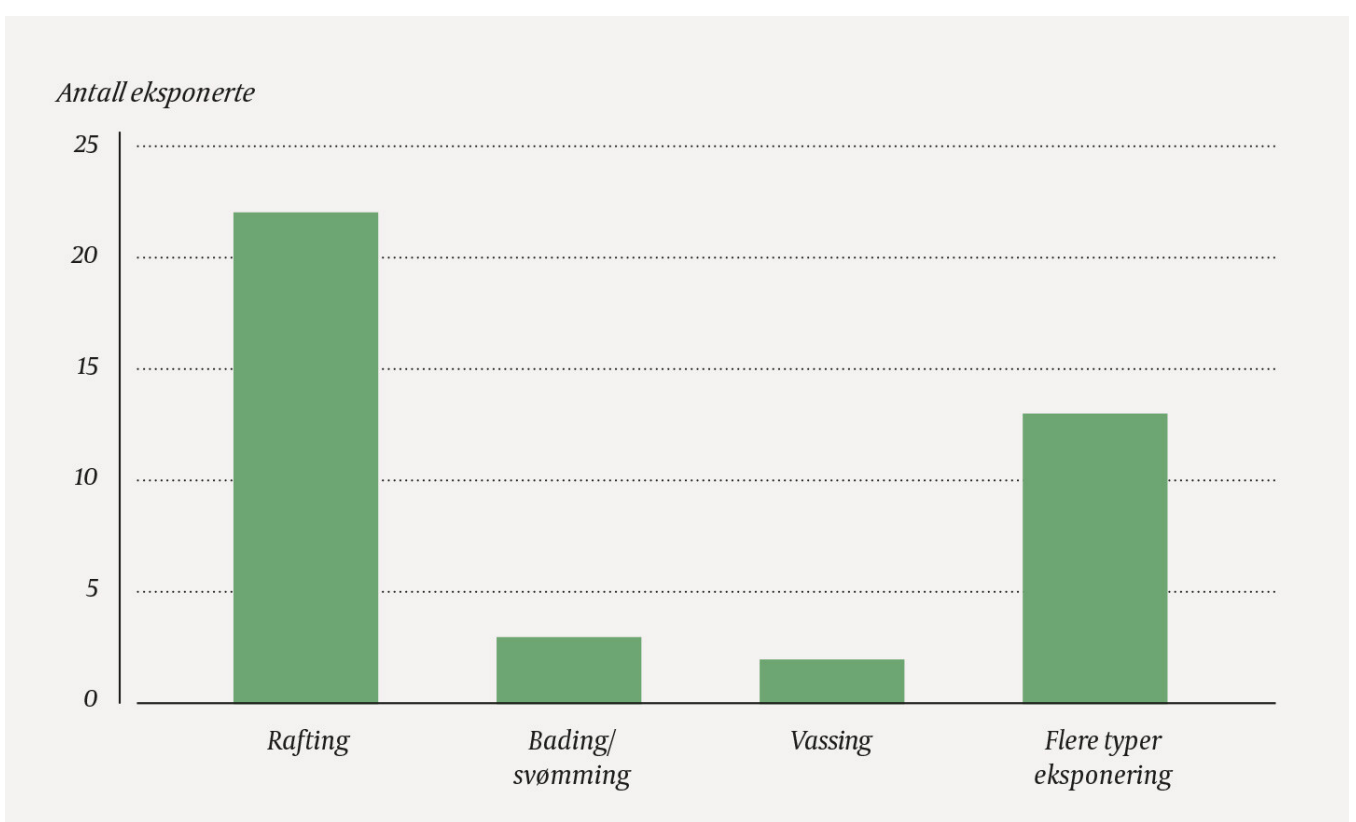

Figur 2 Typer av ferskvannseksponering blant studenter som var seropositive for schistosomiasis. «Flere typer eksponering» består av kombinasjoner av de tre andre eksponeringstypene.

\section{Diskusjon}

En oppsiktsvekkende stor andel personer i denne studien testet positivt for Schistosomaantistoff etter kortvarig ferskvannseksponering i Afrika. Det er en vanlig oppfatning blant reisende at schistosomiasis bare smitter i stillestående vann, og studentene ble fortalt lokalt at rafting ikke utgjorde noen risiko for Schistosoma-smitte. Hos over halvparten av studentene ( 55 \%) i vår studie var rafting eneste oppgitte ferskvannskontakt, selv om vi ikke kan utelukke muligheten for at studenter kan ha blitt smittet via husholdningsvann. Cercarier kan være infeksiøse i to-tre dager og kan smitte via husholdningsvann dersom det benyttes overflatevann som ikke er behandlet $(\underline{2}, \underline{12})$. En annen studie av 69 personer med ferskvannskontakt i øvre Nilen fant schistosomiasis hos $17 \%$ av deltakerne (13). 
Et fåtall av de seropositive personene rapporterte om symptomer i tiden etter eksponeringen som potensielt kunne være relatert til kronisk schistosomiasis, som plager fra urinveier, genitalia og tarm eller tretthet som følge av kronisk inflammasjon, og langt de fleste var asymptomatiske (tabell 2). Svømmekløe, som kan forekomme etter cercarienes penetrasjon av huden, er rapportert hos 7-36\% blant reisende med schistosomiasis $(7, \underline{11})$. Kun $5 \%$ av personene i denne studien kunne erindre symptomer på dette. Kun én person som var seropositiv, rapporterte symptomer forenlige med akutt schistosomiasis.

Siden Schistosoma-antistoff vil kunne påvises i blodet i flere år etter at infeksjonen har gått over av seg selv eller etter behandling (14.), kan et ukjent antall studenter med positiv serologisk test ha sanert infeksjonen spontant. Ettersom ormene potensielt kan leve i flere tiår, er det likevel sannsynlig at mange fortsatt hadde en aktiv infeksjon, og alle de seropositive studentene ble anbefalt behandling med prazikvantel. Den viktigste grunnen til å behandle schistosomiasis hos reisende er risikoen for nevroschistosomiasis.

Prazikvantel regnes som svært effektivt mot schistosomiasis, men er uregistrert og kostbart i Norge. Anbefalt dosering varierer fra 40 til $60 \mathrm{mg} / \mathrm{kg}$ fordelt på to doser én dag $(\underline{2}, 7, \mathbf{1 5}, \underline{16})$. Prazikvantel har bare effekt på voksne ormer, og siden parasittmodningen antas å ta opptil tolv uker, anbefales det å avvente behandling til minst tre måneder etter

ferskvannseksponering, eventuelt å gjenta kuren tre måneder etter siste eksponering om man er behandlet på et tidligere tidspunkt. Behandlingen har lite bivirkninger og kan gis til gravide.

Andre tester enn de serologiske hadde lav eller ingen diagnostisk verdi i denne studien. Mikroskopi for påvisning av egg i urin og feces brukes ofte som rutinediagnostikk ved schistosomiasis, men er lite sensitivt hos reisende på grunn av kortvarig eksponering og derav lav ormebyrde og eggproduksjon (므), noe vi også fant i denne studien.

Serologisk test er den mest sensitive tilgjengelige diagnostiske metoden hos reisende og har også høy spesifisitet (> 95\%). Den er derfor egnet til å påvise lavgradig infeksjon hos personer som ikke tidligere har vært eksponert eller behandlet for schistosomiasis. Den største svakheten til testen er manglende evne til å skille aktiv fra gjennomgått infeksjon. Den er heller ikke $100 \%$ sensitiv, og noen tilfeller av schistosomiasis kan påvises ved mikroskopi eller PCR, selv om serologisk test er negativ $(\underline{6}, 17$.$) . Både serologisk analyse og$ direkte påvisning av egg i urin eller feces vil være negativ inntil parasittene er kjønnsmodne og har startet eggproduksjon. Diagnostikken er derfor ikke sikker før minst tolv uker etter siste eksponering. Serologisk diagnostikk har hittil blitt utført ved utenlandske laboratorier og har vært svært kostbar. En rimelig Schistosomaantistoffundersøkelse er nå tilgjengelig ved det nyetablerte referanselaboratoriet for parasittserologi ved Universitetssykehuset Nord-Norge, Troms $\emptyset$.

Ved Oslo universitetssykehus og Haukeland universitetssjukehus tilbys nå sanntids-PCRundersøkelse for påvisning av Schistosoma spp. i urin, feces og serum. PCR øker sensitiviteten i forhold til mikroskopi (17-19). og er ikke avhengig av en godt trent mikroskopør. PCR-undersøkelse av serum kan påvise infeksjon kun få uker etter eksponering, og er en sensitiv metode forutsatt at det brukes repetitive sekvenser i Schistosoma-genomet som målområde $(\underline{17}, \underline{18}, \underline{20}, \underline{21})$. På grunn av tilstedeværelsen av DNA fra retinerte egg kan PCR være positiv i over et år etter fullført behandling (17.).

En annen interessant diagnostisk metode er antigentesting, der påvisning av sirkulerende antigen (circulating anodic antigen, CAA) i serum virker mest lovende med tanke på diagnostikk av reisende og vurdering av behandlingsrespons (19).). Testen er ennå ikke kommersielt tilgjengelig, og den praktiske nytteverdien er foreløpig usikker.

Det er flere begrensninger som kan ha påvirket resultatene i denne observasjonsstudien. Mange år mellom eksponering og diagnostikk kan føre til mangelfull erindring av symptomer, slik at beskrivelsene av disse blir mindre nøyaktige. Det hadde vært ønskelig med mikroskopi og PCR-unders $ø$ kelse av urin og feces samt andre diagnostiske tester fra alle deltakerne, men mange avsto fra dette ettersom serologisk analyse er enkelt å utføre og 
mest sensitivt. Vi har ikke kartlagt tidligere opphold i endemiske områder blant studentene, og det kan derfor ikke utelukkes at noen har bodd i endemisk område og blitt eksponert for schistosomiasis tidligere, hvilket vil kunne gi positiv serologisk test. Det hadde også vært ønskelig med data fra de studentene som ikke var eksponert for ferskvann, som en negativ kontroll, men grunnet svært kostbar serologisk test og begrensede ressurser har vi ikke dette.

Funnene i denne studien understreker at ferskvannskontakt i Afrika er vanlig blant reisende, og at forekomsten av schistosomiasis kan være høy også blant personer som er eksponert for ferskvann i kort tid. Det er sannsynlig at infeksjonen er underdiagnostisert i Norge siden mange ikke får symptomer. Ved utredning av schistosomiasis hos asymptomatiske reisende uten tidligere eksponering anbefaler vi primært serologisk testing alene. Vi anbefaler at serologisk testing suppleres med PCR og/eller mikroskopi ved symptomer samt ved utredning av personer med lengre opphold i endemiske områder. Ved påvist schistosomiasis anbefales prazikvantel 40-6o mg/kg/dag tatt én dag. Både diagnostikk og behandling anbefales utført minst tre måneder etter siste mulige eksponering. Kontroll av serologisk status etter behandling er ikke indisert, da antistoff vil kunne påvises i lang tid etter sanert infeksjon. Kjøp og inntak av prazikvantel lokalt kort tid etter eksponering er vanlig blant reisende, men frarådes, da tidlig behandling ikke har effekt. Schistosomiasis er en potensielt alvorlig sykdom, og reisende bør advares mot hudkontakt med ferskvann i Afrika og i endemiske områder i Latin-Amerika og Asia.

Artikkelen er fagfellevurdert.

\section{LITTERATUR}

1. World Health Organization. Schistosomiasis. https://www.who.int/en/news-room/factsheets/detail/schistosomiasis Lest 23.11.2020.

2. Colley DG, Bustinduy AL, Secor WE et al. Human schistosomiasis. Lancet 2014; 383: 2253-64. [PubMed]

3. Ferrari TCA, Moreira PRR. Neuroschistosomiasis: clinical symptoms and pathogenesis. Lancet Neurol 2011; 10: 853-64. [PubMed]

4. Deol AK, Fleming FM, Calvo-Urbano B et al. Schistosomiasis - Assessing Progress toward the 2020 and 2025 Global Goals. N Engl J Med 2019;381: 2519-28. [PubMed][CrossRef]

5. Boissier J, Grech-Angelini S, Webster BL et al. Outbreak of urogenital schistosomiasis in Corsica (France): an epidemiological case study. Lancet Infect Dis 2016; 16: 971-9. [PubMed][CrossRef]

6. Coltart CE, Chew A, Storrar N et al. Schistosomiasis presenting in travellers: a 15 year observational study at the Hospital for Tropical Diseases, London. Trans R Soc Trop Med Hyg 2015; 109: 214-20. [PubMed][CrossRef]

7. Clerinx J, Van Gompel A. Schistosomiasis in travellers and migrants. Travel Med Infect Dis 2011; 9: 624. [PubMed][CrossRef]

8. Rose MF, Zimmerman EE, Hsu L et al. Atypical presentation of cerebral schistosomiasis four years after exposure to Schistosoma mansoni. Epilepsy Behav Case Rep 2014; 2: 80-5. [PubMed][CrossRef]

9. Skorpen PK, Thoresen H. En utenlandsk mann med hodepine og ryggsmerter. Tidsskr Nor Legeforen 2017; 137: 545-8. [PubMed][CrossRef]

10. Zaqout A, Abid FB, Murshed K et al. Cerebral schistosomiasis: Case series from Qatar. Int J Infect Dis 2019; 86:167-70. [PubMed][CrossRef]

11. Lingscheid T, Kurth F, Clerinx J et al. Schistosomiasis in European travelers and migrants: Analysis of 14 years TropNet surveillance data. Am J Trop Med Hyg 2017; 97: 567-74. [PubMed][CrossRef]

12. Braun L, Grimes JET, Templeton MR. The effectiveness of water treatment processes against schistosome cercariae: A systematic review. PLoS Negl Trop Dis 2018; 12: eooo6364. [PubMed] [CrossRef]

13. Morgan OW, Brunette G, Kapella BK et al. Schistosomiasis among recreational users of Upper Nile River, Uganda, 2007. Emerg Infect Dis 2010; 16: 866-8. [PubMed][CrossRef] 
14. Utzinger J, Becker SL, van Lieshout L et al. New diagnostic tools in schistosomiasis. Clin Microbiol Infect 2015; 21: 529-42. [PubMed][CrossRef]

15. Ross AG, Chau TN, Inobaya MT et al. A new global strategy for the elimination of schistosomiasis. Int J Infect Dis 2017; 54: 130-7. [PubMed][CrossRef]

16. Liu R, Dong HF, Guo Y et al. Efficacy of praziquantel and artemisinin derivatives for the treatment and prevention of human schistosomiasis: a systematic review and meta-analysis. Parasit Vectors 2011; 4: 201. [PubMed][CrossRef]

17. Guegan H, Fillaux J, Charpentier E et al. Real-time PCR for diagnosis of imported schistosomiasis. PLoS Negl Trop Dis 2019; 13: eooo7711. [PubMed][CrossRef]

18. Weerakoon KG, Gobert GN, Cai P et al. Advances in the diagnosis of human schistosomiasis. Clin Microbiol Rev 2015; 28: 939-67. [PubMed][CrossRef]

19. van Grootveld R, van Dam GJ, de Dood C et al. Improved diagnosis of active Schistosoma infection in travellers and migrants using the ultra-sensitive in-house lateral flow test for detection of circulating anodic antigen (CAA) in serum. Eur J Clin Microbiol Infect Dis 2018; 37: 1709-16. [PubMed] [CrossRef]

20. Cnops L, Soentjens P, Clerinx J et al. A Schistosoma haematobium-specific real-time PCR for diagnosis of urogenital schistosomiasis in serum samples of international travelers and migrants. PLoS Negl Trop Dis 2013; 7: e2413. [PubMed][CrossRef]

21. Wichmann D, Panning M, Quack T et al. Diagnosing schistosomiasis by detection of cell-free parasite DNA in human plasma. PLoS Negl Trop Dis 2009;3: e422. [PubMed][CrossRef]

Publisert: 15. februar 2021. Tidsskr Nor Legeforen. DOI: 10.4045/tidsskr.20.0268

Mottatt 27.3.2020, første revisjon innsendt 25.7.2020, godkjent 23.11.2020.

Publisert under åpen tilgang CC BY-ND. Lastet ned fra tidsskriftet.no 26. april 2023. 